\title{
SOIL-APPLIED SILICON DECREASES SEVERITY OF WHEAT SPOT BLOTCH ON SILICON-DEFICIENT SOILS ${ }^{(1)}$
}

\author{
Luiz Antônio Zanão Júnior ${ }^{(2)}$, Renildes Lúcio Ferreira Fontes ${ }^{(3)}$, Paulo \\ Henrique Moreira Coelho ${ }^{(4)}$, Gaspar Henrique Korndörfer ${ }^{(5)}$ \& Laércio \\ Zambolim $^{(3)}$
}

\begin{abstract}
SUMMARY
Spot bloth caused by Bipolaris sorokiniana is an important wheat desease mainly in hot and humid regions. The aim of this study was to evaluate the response of wheat to different sources and modes of Si application, as related to the severity of wheat spot blotch and plant growth, in two Si-deficient Latosols (Oxisols). An greenhouse experiment was arranged in a $2 \times 5$ factorial completely randomized design, with eight replications. The treatments consisted of two soils (Yellow Latosol and Red Latosol) and five Si supply modes (no Si application; Si applied as calcium silicate and monosilicic acid to the soil; and $\mathrm{Si}$ applied as potassium silicate or monosilicic acid to wheat leaves). No significant differences were observed between the two soils. When $\mathrm{Si}$ was applied to the soil, regardless the $\mathrm{Si}$ source, the disease incubation period, the shoot dry matter yield and the Si content in leaves were greater. Additionally, the final spot blotch severity was lower and the area under the spot blotch disease progress curve and the leaf insertion angle in the plant were smaller. Results of Si foliar application were similar to those observed in the control plants.
\end{abstract}

Index terms: Triticum aestivum L., Bipolaris sorokiniana (Sacc. in Sorok.), plant nutrition, $\mathrm{Si}$.

\footnotetext{
(1) Recebido para publicação em março de 2009 e aprovado em janeiro de 2010.

(2) Agronomic Institute of Paraná - IAPAR. CEP 84001-970 Ponta Grossa (PR). E-mail: lzanao@iapar.br

(3) Department of Soil Science and Plant Nutrition, Federal University of Viçosa - UFV. CEP 36570-000 Viçosa (MG). E-mail: renildes@ufv.br

(4) Department of Plant Pathology, UFV. E-mail: zambolim@ufv.br

(5) Institute of Agronomy, Federal University of Uberlândia, CEP 38400-902 Uberlândia (MG). E-mail: ghk53@uol.com.br
} 


\title{
RESUMO: SILÍCIO APLICADO NO SOLO REDUZ A SEVERIDADE DA MANCHA-MARROM DO TRIGO EM SOLOS COM BAIXOS TEORES DESSE ELEMENTO
}

\begin{abstract}
A mancha-marrom, causada por Bipolaris sorokiniana em plantas de trigo é de grande importância em regiões quentes e úmidas. O objetivo deste trabalho foi avaliar a resposta do trigo a diferentes fontes e modos de aplicação de silício na severidade da mancha-marrom e no crescimento das plantas em dois Latossolos com níveis deficientes de Si. O experimento foi conduzido em casa de vegetação, e os tratamentos, dispostos em esquema fatorial $2 x 5$ [dois tipos de solo (Latossolo Amarelo e Latossolo Vermelho) e cinco modos de fornecimento de Si (sem aplicação; aplicação no solo, tendo o silicato de cálcio ou o ácido monossilícico como fontes; $\mathrm{e}$ o Si aplicado via foliar, usando o silicato de potássio ou o ácido monossilícico como fontes)] com oito repetições, em delineamento inteiramente casualizado. Não houve efeito do tipo de solo em nenhuma característica avaliada. Quando o Si foi aplicado no solo, independentemente da fonte, o período de incubação da doença, a produção de matéria seca da parte aérea e o teor de Si nas folhas foram maiores. Adicionalmente, a severidade final da mancha-marrom foi menor e a área sob a curva do progresso da doença assim como o ângulo de inserção foliar foram menores. A aplicação do Si via foliar não foi eficiente, não diferindo da testemunha.
\end{abstract}

Termos de indexação: Triticum aestivum L., Bipolaris sorokiniana (Sacc. in Sorok.), nutrição de plantas, Si.

\section{INTRODUCTION}

Wheat (Triticum aestivum L.) production in Brazil, in the period from 2001 to 2006 , ranged from 2.23 to 6.07 million tons. This quantity was lower than the wheat consumption of around 10-12 million tons in the same period (CONAB, 2007), demonstrating the need for increased production of this crop in Brazil.

The southern region of Brazil accounted for about $90 \%$ of the country's wheat production from 2001 to 2006 (FNP, 2006). The crop has also expanded to the Cerrado region, with promising results, as shown by yields of over $7 \mathrm{t} \mathrm{ha}^{-1}$, making wheat an option for crop rotation in that region (Souza \& Ramalho, 2001).

A large number of fungal diseases have had an economic impact on wheat production in Brazil, by causing heavy yield losses as well as lower grain quality. Although these losses vary annually, Fernandes \& Picinini (1999) reported, in 12 years of experimentation, an average loss of $44.61 \%$ due to diseases, equivalent to an accumulated loss of $1,152 \mathrm{~kg} \mathrm{ha}^{-1}$.

Among the fungal diseases, spot blotch caused by the fungus Bipolaris sorokiniana (Sacc. in Sorok.) causes damage to the whole wheat plant, from leaves to roots. The pathogen is widely distributed in wheatproducing areas around the world, but is far more aggressive in hot and humid regions. The economic impact is therefore strongest in countries such as India, Bangladesh, Nepal, and Brazil (Joshi et al., 2004).

Currently, alternative methods of disease control have been sought with a view to a method that would be ecologically adequate, economically viable and sustainable in practice. In some situations, crop fertilization with silicon may fulfill these requirements. Fauteux et al. (2005) reported the success of Si application in reducing the incidence or severity of several diseases in diverse crops, including wheat.

The expansion of the wheat crop in Brazil occurs mainly in the Cerrado region, where soil Si availability is low. Due to the attributes of Cerrado soils, it is to be expected that the plant response to Si application will be positive, mainly for Si-accumulating plants, as in the case of crops of the Gramineae family, including wheat. Si is absorbed monosilicic acid $\left(\mathrm{H}_{4} \mathrm{SiO}_{4}\right)$ and the wheat root system is efficient in $\mathrm{Si}$ uptake (Rafi \& Epstein,1999).

In crops such as grapes and cucumber, the severity of some diseases was reduced by foliar silicon application, as well as by Si application to the soil (Menzies et al., 1992; Bowen et al., 1992). These authors attribute desease reduction to a physical barrier formed by the silicate deposition on the leaf surface, preventing the penetration of the fungal hyphae into plant tissue. Since an osmotic effect of silicate may occur at high concentrations, the $\mathrm{Si}$ source may also be relevant (Liang et al., 2005).

The objective of this study was to evaluate the response of wheat to different sources and modes of $\mathrm{Si}$ application, as related to spot blotch severity of and plant growth, in two types of Si-deficient Latosols (Oxisols).

\section{MATERIAL AND METHODS}

The experiment was carried out in a greenhouse, in the winter of 2006. Treatments were arranged in a 
$2 \times 5$ factorial design with two soils (Yellow Latosol and Red Latosol) and Si application methods [controlno Si application; soil-applied $\mathrm{Si}$ as wollastonite $\left(\mathrm{CaSiO}_{3}\right)$; soil applied $\mathrm{Si}$ as monosilicic acid $\left(\mathrm{H}_{4} \mathrm{SiO}_{4}\right)$ foliar-applied $\mathrm{Si}$ as monosilicic acid $\left(\mathrm{H}_{4} \mathrm{SiO}_{4}\right)$; and foliar-applied $\mathrm{Si}$ as potassium silicate $\left.\left(\mathrm{K}_{2} \mathrm{SiO}_{3}\right)\right]$. The experiment was arranged in a randomized block design with eight replications. The Si rates applied to the soil were 0.312 and $0.402 \mathrm{~g} \mathrm{dm}^{-3}$ to the Yellow Latosol and Red Latosol, respectively, and $4.8 \mathrm{~g} \mathrm{~L}^{-1}$ to the leaves. Experimental units consisted of a $2.5 \mathrm{dm}^{3}$ pot with $2.0 \mathrm{dm}^{3}$, of soil and three wheat plants per pot.

A typic dystrophic Yellow Latosol and a dystrophic Red Latosol considered Si-deficient, were used in the trial. The Yellow Latosol contained $580 \mathrm{~g} \mathrm{~kg}^{-1}$ clay; $\mathrm{pH} \mathrm{H}_{2} \mathrm{O}(1: 2.5)=4.93 ; \mathrm{P}$ (Mehlich-1) $=0.4 \mathrm{mg} \mathrm{dm}^{-3}$; $\mathrm{K}, \mathrm{Al}^{3+}, \mathrm{Ca}^{2+}, \mathrm{Mg}^{2+}, \mathrm{H}+\mathrm{Al}=0.01,0.11,0.05,0.08$, and $3.8 \mathrm{cmol}_{\mathrm{c}} \mathrm{dm}^{-3}$, respectively; base saturation $=3.6 \%$; organic matter $=20.3 \mathrm{~g} \mathrm{~kg}^{-1} ; \mathrm{B}, \mathrm{Cu}, \mathrm{Fe}$, and $\mathrm{Mn}=$ $0.20,0.15,19.0$, and $1.80 \mathrm{mg} \mathrm{dm}^{-3}$, respectively; field capacity of $0.259 \mathrm{~kg} \mathrm{~kg}^{-1}$ and density of $1.10 \mathrm{~kg} \mathrm{dm}^{-3}$. Silicon content extracted by $\mathrm{CaCl}_{2}$, was $2.4 \mathrm{mg} \mathrm{dm}^{-3}$. The dystrophic Red Latosol contained $180 \mathrm{~g} \mathrm{~kg}^{-1}$ clay; $\mathrm{pH} \mathrm{H} \mathrm{H}_{2} \mathrm{O}(1: 2.5)=4.90 ; \mathrm{P}($ Mehlich-1 $)=0.3 \mathrm{mg} \mathrm{dm}^{-3}$; $\mathrm{K}, \mathrm{Al}^{3+}, \mathrm{Ca}^{2+}, \mathrm{Mg}^{2+}, \mathrm{H}+\mathrm{Al}=0.02,0.25,0.01,0.03$, and $3.8 \mathrm{cmol}_{\mathrm{c}} \mathrm{dm}^{-3}$, respectively; base saturation = $2.3 \%$; organic matter $=9.1 \mathrm{~g} \mathrm{~kg}^{-1} ; \mathrm{B}, \mathrm{Cu}, \mathrm{Fe}$, and $\mathrm{Mn}$ $=0.32,0.06,33.50$, and $5.00 \mathrm{mg} \mathrm{dm}^{-3}$, respectively; field capacity of $0.135 \mathrm{~kg} \mathrm{~kg}^{-1}$ and density of $1.02 \mathrm{~kg} \mathrm{dm}^{-3}$. Silicon content extracted by $\mathrm{CaCl}_{2}$ was $1.2 \mathrm{mg} \mathrm{dm}^{-3}$.

Each pot contained $2.2 \mathrm{dm}^{3}$ of previously limed soil. To the Yellow Latosol and Red Latosol, respectively, $1 \mathrm{~g} \mathrm{dm}^{-3}$ and $1.2 \mathrm{~g} \mathrm{dm}^{-3} \mathrm{CaCO}_{3}$ were applied. The soil treated with wollastonite was not limed since, besides providing $\mathrm{Si}$, wollastonite has liming properties. The wollastonite quantity applied to the soil was calculated to balance the Ca provided by $\mathrm{CaCO}_{3}(40 \% \mathrm{Ca})$. To the Yellow Latosol and Red Latosol, respectively, $1.29 \mathrm{~g} \mathrm{dm}^{-3}$ and $1.55 \mathrm{~g} \mathrm{dm}^{-3}$ wollastonite were applied, providing 0.312 and $0.402 \mathrm{~g} \mathrm{dm}^{-3} \mathrm{Si}$. In all treatments, $0.20 \mathrm{~g} \mathrm{dm}^{-3} \mathrm{MgCO}_{3}$ was applied along with the liming material. After homogenization of the limed soil, deionized water was added to raise the moisture level to $80 \%$ of field capacity and the mixture was incubated for 30 days. The amount of monosilicic acid applied to the soil was calculated to provide the same amount of $\mathrm{Si}$ as supplied by wollastonite. This value was determined by passing a solution of potassium silicate $\left(12 \% \mathrm{Si}\right.$ and $13 \% \mathrm{~K}_{2} \mathrm{O}$ ) through a cation exchange resin column (Ma et al., 2001).

After the incubation period, $400 \mathrm{mg} \mathrm{dm}^{-3} \mathrm{P}$ $\left(\mathrm{CaHPO}_{4}\right)$ per pot was added and soil samples $\left(0.2 \mathrm{dm}^{3}\right)$ were withdrawn from each experimental unit. The soil samples were analyzed to determine $\mathrm{pH}$ in water (1:2.5), Ca content by atomic absorption spectrophotometry and Si by colorimetry (Korndörfer et al., 2004). For these analyses, two composite samples were prepared for each soil, one from replications treated with calcium carbonate and the other from the replications treated with wollastonite $\left(\mathrm{CaSiO}_{3}\right)$.

Eight wheat (cv. BR18) seeds per pot were sown at a depth of $1 \mathrm{~cm}$ and thinned a first time five days after plant emergence (DAE), leaving six seedlings per pot. At that time the first N, K, S and micronutrient supply was applied as $25 \mathrm{~mL} \mathrm{dm}^{-3}$ nutrient solution. Ten DAE, the second thinning left four plants per pot. The second and third $\mathrm{N}$ and micronutrient applications occurred 15 and $30 \mathrm{DAE}$, respectively, with $25 \mathrm{~mL} \mathrm{dm}^{-3}$ nutrient solution. Altogether, the applications (in $\mathrm{mg} \mathrm{kg}^{-1}$ ) consisted of: $160 \mathrm{~N}, 210 \mathrm{~K}, 60 \mathrm{~S}, 60 \mathrm{Mg}, 1 \mathrm{~B}, 1.5 \mathrm{Cu}, 2 \mathrm{Fe}, 3.5 \mathrm{Mn}$, $0.2 \mathrm{Mo}$, and $5.00 \mathrm{Zn}$, using the following nutrient sources: $\mathrm{NH}_{4} \mathrm{NO}_{3}, \mathrm{CO}\left(\mathrm{NH}_{2}\right)_{2}, \mathrm{KCl}, \mathrm{K}_{2} \mathrm{SO}_{4}, \mathrm{MgSO}_{4}$, $\mathrm{H}_{3} \mathrm{BO}_{3}, \mathrm{CuSO}_{4} .5 \mathrm{H}_{2} \mathrm{O}, \mathrm{FeSO}_{4} .7 \mathrm{H}_{2} \mathrm{O}, \mathrm{MnCl}_{2} .4 \mathrm{H}_{2} \mathrm{O}$, $\left(\mathrm{NH}_{4}\right)_{6} \mathrm{Mo}_{7} \mathrm{O}_{24} \cdot 4 \mathrm{H}_{2} \mathrm{O}$, and $\mathrm{ZnSO}_{4} \cdot 7 \mathrm{H}_{2} \mathrm{O}$. Soil moisture in the pots was maintained at around $80 \%$ of field capacity by the addition of deionized water.

Si was applied to the leaves 44 DAE by a nebulizer coupled to an air compressor. The $\mathrm{pH}$ of the solutions was adjusted to 6.0 with the addition of $2 \mathrm{~mol} \mathrm{~L}^{-1} \mathrm{HCl}$. The quantity applied to each pot was previously determined for a maximum moisture retention on the leaf surface to avoid solution run-off from the surface. Potassium silicate was applied at a rate of $40 \mathrm{~g} \mathrm{~L}^{-1}$ $\left(4.8 \mathrm{~g} \mathrm{~L}^{-1} \mathrm{Si}\right)$ and the same amount of Si was applied as monosilicic acid. The plants treated with Si via soil and the control plants were sprayed with distilled water, adjusting the $\mathrm{pH}$ to 6.0.

Twenty four hours after Si foliar-application, the plants were transferred to an inoculation chamber with a pathogenic isolate inoculation of $B$. sorokiniana. To prepare the inoculum suspension, the isolate conserved on sterile filter paper at $-80^{\circ} \mathrm{C}$ was distributed in Petri dishes containing potato dextrose agar. After distribution, the dishes were transferred to a BOD incubator with fluorescent light (12 h continuous photoperiod) at $25{ }^{\circ} \mathrm{C}$, for approximately 10 days, until conidia were abundantly produced. The inoculum suspension was prepared by adding $10 \mathrm{~mL}$ of distilled water to each dish and the conidia were scraped off the surface with a spatula. The suspension was filtered through gauze to eliminate mycelium fragments and the culture medium. After filtering, the conidial suspension was adjusted to $10^{4}$ conidia per $\mathrm{mL}$.

Three leaves of each plant were selected for evaluation. Plants were inoculated by spraying the conidial suspension with a nebulizer (De Vilbiss no. 15). Immediately after inoculation, the plants were transferred to a growth chamber $\left(25 \pm 2^{\circ} \mathrm{C}\right.$ and $95 \pm$ $2 \%$ relative humidity), under nebulizer spraying for $40 \mathrm{~s}$ every $30 \mathrm{~min}$, during $12 \mathrm{~h}$, in a continuous photoperiod of $12 \mathrm{~h}$. The plants were then transferred to chambers $\left(18 \pm 2{ }^{\circ} \mathrm{C}\right)$ until the end of the evaluations. 
The incubation period, number of lesions per $\mathrm{cm}^{2}$ leaf area and spot blotch severity were evaluated six days after inoculation. The incubation period was determined by observing the presence of the first lesions on the leaves every three hours, from the beginning of inoculation until the moment when lesions became visible on all selected leaves of all replications.

The spot blotch severity was evaluated every $24 \mathrm{~h}$ after inoculation by visual determination of the percentage of infected leaf area. The disease severity data were used to estimate the area under the disease progress curve (AUSBPC), which was calculated by the equation proposed by Shaner \& Finney (1977).

The final disease severity was evaluated six days after inoculation, observing the general aspect of each entire plant and attributing to it a grade based on the percentage of leaf area covered with lesions.

With a compass and a protractor, the leaf insertion angle of the leaf under the flag leaf of each plant was measured and the average angle for the plants in each pot calculated.

To evaluate shoot dry matter yield, the plants were washed with distilled water and later again with a solution of neutral biodegradable detergent $1 \mathrm{~mL} \mathrm{~L}^{-1}$, $\mathrm{HCl} 0,1 \mathrm{~mol} \mathrm{~L}^{-1}$ and finally with distilled water. The plants were oven-dried to constant dry weight by forced air circulation at $65{ }^{\circ} \mathrm{C}$.

The leaves were ground in a Wiley mill and passed through a $0.84 \mathrm{~mm}$ sieve screen. Dry matter was mineralized by a nitric-perchoric $\left(3: 1, \mathrm{v} \mathrm{v}^{-1}\right)$ solution and the $\mathrm{K}$ content determined by flame spectrophotometry. The Si content was determined by alkaline digestion and the colorimetric method (Korndörfer et al., 2004).

The experiment was conducted twice and the data from each variable were grouped, since homogeneity of variation was confirmed by the Cochran test (Gomez \& Gomez, 1984). Analysis of variance was performed using the Statistical and Genetic Analysis System (SAEG) and the means were compared by the Tukey test at $5 \%$.

\section{RESULTS AND DISCUSSION}

The effect of calcium carbonate $\left(\mathrm{CaCO}_{3}\right)$ and wollastonite $\left(\mathrm{CaSiO}_{3}\right)$ on the soil $\mathrm{pH}$ in the two soils was similar (Table 1), as also reported by Pereira et al. (2007). Besides supplying Si to the plants, wollastonite is an efficient liming material for the soil and is considered a standard Si source.

No significant effect was observed regarding the soil type for any of the variables analyzed, nor any interaction between the soil and Si application type. Possibly, similar levels of available Si content and the similarity of chemical and physical properties of the two soils may have been the cause that the soil type was not significant for any of the variables evaluated (Table 2).

The K leaf content varied from 30.90 to $33.27 \mathrm{~g} \mathrm{~kg}^{-1}$ (Table 3), within the range considered adequate for wheat (Malavolta et al., 1997). This was the only variable with no significant difference in response to the Si sources and application modes, even when potassium silicate was applied to the leaves. This may be due to the $210 \mathrm{mg} \mathrm{dm}^{-3} \mathrm{~K}$ supplied to the plants by the regular fertilizer application, which may have resulted in "luxury consumption" by the plants.

When Si was foliar-applied, irrespective of the source, all results were similar to those observed for the control plants (Tables 3 and 4). On the other hand, when Si was applied to the soil, leaf Si content was on average 4.5 times greater than in the control, regradless the source (Table 3). This may have been

Table 1. Values of $\mathrm{pH}$ in water, $\mathrm{Ca}$ and $\mathrm{Si}$ content after incubation of soils with liming materials

\begin{tabular}{lccc}
\hline Treatment & $\begin{array}{c}\text { pH water } \\
\mathbf{1 : 2 . 5}\end{array}$ & $\mathbf{C a}^{(1)}$ & $\mathbf{S i}^{(2)}$ \\
& & $\mathrm{cmol}_{\mathrm{c}} \mathrm{dm}^{-3}$ & $\mathrm{mg} \mathrm{dm}^{-3}$ \\
& & 4.16 & 2.30 \\
Yellow Latosol $+\mathrm{CaCO}_{3}$ & 6.53 & 4.29 & 7.40 \\
Yellow Latosol $+\mathrm{CaSiO}_{3}$ & 6.67 & 2.72 & 1.20 \\
Red Latosol $+\mathrm{CaCO}_{3}$ & 6.46 & 2.68 & 6.90 \\
Red Latosol $+\mathrm{CaSiO}_{3}$ & 6.55 & 10.5 & 7.89 \\
CV (\%) & 4.19 & & \\
\hline
\end{tabular}

(2) Extractor: $\mathrm{KCl} 1 \mathrm{~mol} \mathrm{~L}^{-1}{ }^{(2)}$ Extractor: $\mathrm{CaCl}_{2} 0.01 \mathrm{~mol} \mathrm{~L}^{-1}$.

Table 2. Shoot dry matter yield (SDMY), leaf insertion angle, $K$ and $S i$ leaf content, incubation period, lesions per $\mathrm{cm}^{2}$ of leaf area, final spot blotch severity and area under the spot blotch disease progress curve (AUSBPC) in wheat cultivated in two soils and with different $\mathrm{Si}$ application modes after inoculation with $B$. sorokiniana

\begin{tabular}{lrr}
\hline \multirow{2}{*}{ Measurement } & \multicolumn{2}{c}{ Soil } \\
\cline { 2 - 3 } & $\begin{array}{c}\text { Yellow } \\
\text { Latosol }\end{array}$ & $\begin{array}{c}\text { Red } \\
\text { Latosol }\end{array}$ \\
\hline SDMY, g/pot & $2.34^{\mathrm{ns}}$ & 2.25 \\
Leaf insertion angle, $^{\circ}$ & $36.48^{\mathrm{ns}}$ & 36.77 \\
K leaf content, g kg-1 & $31.74^{\mathrm{ns}}$ & 31.86 \\
Si leaf content, g kg-1 & $9.44^{\mathrm{ns}}$ & 8.10 \\
Incubation period, h & $19.80^{\mathrm{ns}}$ & 21.00 \\
${\text { Leaf lesions, }{ }^{\text {o. }} \text { per cm }}^{2}$ & $16.20^{\mathrm{ns}}$ & 16.05 \\
Final severity of spot blotch (\%) & $76.09^{\mathrm{ns}}$ & 71.56 \\
AUSBPC & $9,430.25^{\mathrm{ns}}$ & $9,317.58$ \\
\hline ns. not significant at $5 \%$ by F-test. & &
\end{tabular}


Table 3. Shoot dry matter yield (SDMY), leaf insertion angle (LIA), K leaf content (KLF) and Si leaf content (SiLF) in wheat leaves growing under different forms of Si supply and inoculation with B. sorokiniana

\begin{tabular}{|c|c|c|c|c|}
\hline Source - application mode & SDMY & LIA & KLF & SiLF \\
\hline & g/pot & o & \multicolumn{2}{|c|}{$\longrightarrow \mathrm{g} \mathrm{kg}^{-1} \longleftarrow$} \\
\hline Control & $1.71 \mathrm{~b}$ & $40.86 \mathrm{a}$ & $31.72 \mathrm{a}$ & $3.55 \mathrm{~b}$ \\
\hline Wollastonite-soil & $3.08 \mathrm{a}$ & $30.37 \mathrm{~b}$ & $33.27 \mathrm{a}$ & $16.25 \mathrm{a}$ \\
\hline Monosilicic acid-soil & $2.92 \mathrm{a}$ & $30.38 \mathrm{~b}$ & $30.90 \mathrm{a}$ & $15.65 \mathrm{a}$ \\
\hline Monosilicic acid-foliar & $2.13 \mathrm{~b}$ & $40.95 \mathrm{a}$ & $31.73 \mathrm{a}$ & $4.33 \mathrm{~b}$ \\
\hline Potassium silicate-foliar & $2.05 \mathrm{~b}$ & $40.55 \mathrm{a}$ & $31.36 \mathrm{a}$ & $4.20 \mathrm{~b}$ \\
\hline $\mathrm{CV}(\%)$ & 17.17 & 13.99 & 5.09 & 12.45 \\
\hline
\end{tabular}

Means followed by the same letter within a column are not significantly different at the 0.05 level by the Tukey Test.

Table 4. Incubation period (IP), lesions $/ \mathrm{cm}^{2}$ of leaf area (LES), final severity of spot blotch (SEVSB) and area under the spot blotch disease progress curve (AUSBPC) in wheat cultivated in two soils with different forms of Si supply and inoculated with B. sorokiniana

\begin{tabular}{|c|c|c|c|c|}
\hline Source - application mode & PI & LES & SEVBS & AUSBPC \\
\hline & $\mathrm{h}$ & $\mathrm{n}^{\circ} \mathrm{cm}^{-2}$ & $\%$ & $\mathrm{~cm}$ \\
\hline Control & $18.38 \mathrm{~b}$ & $19.38 \mathrm{a}$ & $82.69 \mathrm{a}$ & $11563.63 \mathrm{a}$ \\
\hline Wollastonite-soil & $23.63 \mathrm{a}$ & $11.25 \mathrm{~b}$ & $59.91 \mathrm{~b}$ & $6724.35 \mathrm{~b}$ \\
\hline Monosilicid acid-soil & $22.88 \mathrm{a}$ & $12.63 \mathrm{~b}$ & $65.50 \mathrm{~b}$ & $7554.73 \mathrm{~b}$ \\
\hline Monosilicic acid-foliar & $18.75 \mathrm{~b}$ & $18.63 \mathrm{a}$ & $80.48 \mathrm{a}$ & $10503.13 \mathrm{a}$ \\
\hline Potassium silicate-foliar & $18.38 \mathrm{~b}$ & $19.00 \mathrm{a}$ & $80.55 \mathrm{a}$ & $10523.75 \mathrm{a}$ \\
\hline CV (\%) & 9.51 & 18.37 & 9.90 & 29.37 \\
\hline
\end{tabular}

Means followed by the same letter within a column are not significantly different at the 0.05 level by the Tukey Test.

due to the doses of soil-applied Si, which were near the highest doses commonly used, and to the characteristics of wheat in terms of Si uptake and transport. Rafi \& Epstein (1999) reported that wheat plants accumulated Si rapidly and approximately $90 \%$ of Si absorbed by the plants was transferred to the shoots.

The shoot dry matter yield in plants grown in Sitreated soil (mean of the two treatments) was 1.7 times greater than of control plants and 1.5 times greater than of plants treated with foliar Si application (mean of the two treatments) (Table 3). This difference was 1.2 times greater in plants treated with foliar $\mathrm{Si}$ application than in the control. It seems that $\mathrm{Si}$ absorption in the wheat leaf surface it is not enough to improve plant growth, unlike observed for Si soil application. The wheat Si accumulation capacity (Rafi \& Epstein, 1999) and low Si availability in the Sideficient Latosols used for wheat cultivation certainly contributed to the effectiveness of soil-applied Si. In two rice cultivars grown in low-Si soils, Deren et al. (1994) reported an increment of up to $33 \%$ in the production of plant parts due to fertilization with $2500 \mathrm{mg} \mathrm{dm}^{-3}$ calcium silicate. In wheat, Liang et al. (1994) observed a productivity increase of 4-9\% under soil-applied Si. Korndörfer et al. (1999) stated that a soil where $0.05 \mathrm{~mol} \mathrm{~L}^{-1} \mathrm{CaCl}_{2}$ extracted $\mathrm{Si}$ in a range of $6-8 \mathrm{mg} \mathrm{dm}^{-3}$ indicated a high probability of response to Si application, justifying the inclusion of $\mathrm{Si}$ in fertilization to improve crop yields. The $\mathrm{CaCl}_{2}$ extracted available Si in the two Latosols $\left(1.2 \mathrm{mg} \mathrm{dm}^{-3}\right.$ and $2.4 \mathrm{mg} \mathrm{dm}^{-3}$ ) and the results confirm the need of Si application to this soil type. According to Raij \& Camargo (1973), the soluble Si content of most soils in the Brazilian Cerrado is low. In tropical soils, due to the favourable leaching conditions, $\mathrm{Si}$ is found basically in form of quartz $\left(\mathrm{SiO}_{2}\right)$, opal $\left(\mathrm{SiO}_{2} \cdot \mathrm{nH}_{2} \mathrm{O}\right)$ and other minerals with no plant-available Si (Barbosa Filho et al., 2001). Additionally, Si containing easily leaching minerals is practically inexistent in strongly leached tropical soils (Pereira et al., 2003). It is therefore very likely that crops grown in these soils do respond to soil Si application, mainly crops with a high Si demand such as wheat, rice and sugarcane. 
The leaf insertion angle (LIA) in the control plants and Si-foliar supplied plants were about the same and around 1.3 times greater than in the plants treated with Si soil application (Table 3). The more erect leaves allow a more efficient exploitation of the space available for interception of photosynthetically active radiation. Furthermore, it has been observed that more decumbent leaves shade themselves and reach the maximum leaf area degree earlier than plants with more erect leaves. These effects were shown in the wheat plants treated with Si soil application, where plant architecture was improved by the more erect position of the plant leaves, due to a reduction of approximately 10 degrees in the LIA compared to the plants with foliar-applied Si and controls (Table 3). Certainly, these effects contributed to the greater shoot dry matter yield in wheat plants treated with $\mathrm{Si}$ soil application. Besides the more adequate plant architecture provided by the reduced LIA in wheat (Table 3), it seems that the improvement of water utilization in Si-fertilized rice, as observed by Agarie et al. (1998), also contributed to a shoot dry matter increase. The leaf insertion angle and plant architecture, which are related to plant yield capacity (Keulen, 1986), and the preventive effect of Si against structural and functional deterioration of cell membranes observed in rice plants exposed to environmental stress (Agarie et al., 1998) may have similarly favored wheat plants supplied with Si soil application.

There was a significant increase in the incubation period and a significant decrease in the number of lesions per $\mathrm{cm}^{2}$ of leaf area, in the final severity of the disease and in the area under the spot blotch disease progress curve when Si was applied through the soil, irrespective of the Si source used $(p \leq 0,05)$ (Table 4).

The spot blotch incubation period in plant leaves taking up soil- applied Si lasted approximately $5 \mathrm{~h}$ longer, indicating that the fungus encountered difficulty to penetrate the epidermal cells. Seebold et al. (2001) and Zanão Júnior et al. (2009a) observed a significant increase in the incubation period of leaf blast and brown spot, respectively, in rice grown under high Si supply. The lower severity degree observed in wheat reflects, to a certain extent, the difficulty of the fungus to penetrate the plant epidermis.

On average, there was a reduction of more than seven lesions per $\mathrm{cm}^{2}$ of leaf area in plants taking up soil-applied Si compared to foliar application (Table 4). This may also be explained by the difficulty of the fungus to penetrate the epidermis where $\mathrm{Si}$ was polymerized and Si deposited as hydrated or amorphous silicates $\left(\mathrm{SiO}_{2} \cdot \mathrm{nH}_{2} \mathrm{O}\right)$ under the cuticle (Blackman, 1969). In nutrient solution, Zanão Júnior (2007) observed a thicker epidermis in rice plants cultivated with $2 \mathrm{mmol} \mathrm{L}^{-1}$ Si than in those cultivated without this element.

Lesions developed on leaves of plants taking up soil-applied Si were smaller and fewer than on leaves of plants without Si supply or taking up foliar-applied $\mathrm{Si}$. Without Si or with foliar Si supply, the leaf lesions were larger and coalesced, occupying a large part of the foliar area. Seebold et al. (2001) reported a significant reduction in the expansion rate of blast lesions on rice leaves following application of calcium silicate to the soil. In rice, Kim et al. (2002) observed that the strengthening of epidermal cell walls due to Si supply was responsible for a reduction in the number of leaf lesions. A negative correlation between the numbers of epidermal cells containing $\mathrm{Si}$ deposition, mainly bulliform cells, with the incidence of spot blotch in rice was reported by Nanda \& Gangopadhyay (1984). These authors observed a greater density of Si deposition containing cells in the epidermis of rice leaves of plants supplied with higher rates of soil-applied $\mathrm{Si}$, and that the $\mathrm{B}$. oryzae conidia, although germinated, did not penetrate the epidermal cells.

The severity of spot blotch was 19-26\% lower when Si was soil-applied (Table 4). Rodgers-Gray \& Shaw (2000) observed a reduction (30 to $80 \%$ ) in the severity of important wheat diseases from one growing season to the next when Si was applied to incorporated wheat straw in the soil. Reduction in disease severity of various crop such as rice, cucumber and wheat was attributed to the formation of a physical barrier ( $\mathrm{Si}$ deposition and polymerization beneath the cuticle) and to natural chemical plant defense mechanisms, such as the production of phenolic and phytoalexin compounds (Fauteux et al., 2005).

The area under the spot blotch disease progress curve (AUSBPC) was also significantly reduced in plants supplied with Si to the soil (Table 4). The AUSBPC shows the disease progress in wheat leaves and allows the conclusion that the lesion expansion and, consequently, disease severity, was inversely proportional to soil-applied $\mathrm{Si}$.

The smaller angle of foliar insertion in Si supplied plants may have contributed to the lower severity degree in comparison with plants without $\mathrm{Si}$ supply. Gangopadhyay \& Chatopadhyay (1974) studied the leaf insertion angle of various rice genotypes grown in a greenhouse as related to spot blotch severity and found that the smaller the foliar angle, the lower is the disease severity.

Some studies relate the control of powdery mildew in cucumber, melon, squash and grape vine to the foliar application of potassium silicate at rates of up to $17 \mathrm{mmol} \mathrm{L}^{-1}$ (Menzies et al., 1992; Bowen et al., 1992). These authors attributed the observed effects to a physical barrier formed by the polymerization of potassium silicate on the leaf surface, preventing the fungus penetration into the host plant tissue. Liang et al. (2005) stated that this control may also be due to the osmotic effect of high silicate concentrations from foliar applications. In the present study however, no effect on disease control was observed by foliarapplied Si, regardless of the source. Zanão Júnior et 
al. (2009b) also found no control of rice brown spot by foliar-applied Si. This may have been caused by the absence of silicate polymerization in the leaf due to the $\mathrm{pH}$ adjusted to 6.0 of the applied solution, which may have prevented polymerization.

\section{CONCLUSIONS}

1. The response of wheat plants to Si application is not affected by the different characteristics of the Yellow Latosol and the Red Latosol tested, irrespective of the source and mode of application.

2. Foliar application of $\mathrm{Si}$ is not effective to increase Si contents in wheat leaves.

3. Soil-applied $\mathrm{Si}$ is effective to increase wheat dry matter and wheat spot blotch control, regardless of the $\mathrm{Si}$ source, which is not the case for foliar-applied $\mathrm{Si}$.

4. Soil-applied Si raises the Si wheat leaf content, improves the wheat plant architecture, induces a higher dry matter yield and contributes to a reduced spot blotch disease severity.

\section{ACKNOWLEDGEMENTS}

The authors Fontes, Korndörfer and Zambolim thank the National Council of Scientific and Technological Development (CNPq) for the research fellowship. Zanão Júnior was supported by the Fundação de Amparo à Pesquisa do Estado de Minas Gerais (FAPEMIG) and CNPq. The authors would also like to express their appreciation to Prof. Fabrício de Ávila Rodrigues for technical assistance.

\section{LITERATURE CITED}

AGARIE, S.; HANAOKA, N.; UENO, O.; MIYAZAKI, A.; KUBOTA, F.; AGATA, W. \& KAUFMAN, P.B. Effects of silicon on tolerance to water deficit and heat stress in rice plants (Oryza sativa L.), monitored by electrolyte leakage. Plant Produc. Sci., 1:96-103, 1998.

BARBOSA FILHO, M.P.; SNYDER, G.H.; FAGERIA, N.K.; DATNOFF, L.E. \& SILVA, O.F. Silicato de cálcio como fonte de silício para o arroz de sequeiro. R. Bras. Ci. Solo, 25:325-330, 2001.

BLACKMAN, E. Observations on the development of the silica cells of the leaf sheath of wheat (Triticum aestivum). Canadian J. Bot., 47:827-838, 1969.

BOWEN, P.; MENZIES, J.G. \& EHRET, D. Soluble silicon spray inhibit powdery mildew development on grape leaves. J. Am. Soc. Hortic. Sci., 117:906-912, 1992.

COMPANHIA NACIONAL DE ABASTECIMENTO - CONAB. 2007. Agricultural pointers. <http://www.conab.gov.br/ conabweb/download/safra/4levsafra.pdf $>$ accessed Oct., 2007.
DEREN, C.W.; DATNOFF, L.E.; SNYDER, G.H. \& MARTIN, F.G. Silicon concentration, disease response, and yield components of rice genotypes grown on flooded organic histosols. Crop Sci., 34:733-737, 1994.

FAUTEUX, F.; RÉMUS-BOREL, W.W.; MENZIES, J.G. \& BÉLANGER, R.R. Silicon and plant disease resistance against pathogenic fungi. FEMS Microbiol. Letters, 249:16, 2005 .

FERNANDES, J.M.C. \& PICININI, E.C. Controlando as doenças de trigo na hora certa. Passo Fundo, Embrapa Trigo, 1999. 3p. (Embrapa Trigo. Comunicado Técnico Online, 22). Disponível em: <http://www.cnpt.embrapa.br/ biblio/p_co22.htm> accessed Nov. 11, 2005).

FNP - CONSULTORIA \& COMÉRCIO. Yearbook of Brazilian agriculture 2006. São Paulo, Instituto FNP, 2006. 521p.

GANGOPADHYAY, S. \& CHATTOPADHYAY, S.B. Correlation between leaf angle and incidence of brown spot disease of rice incited by Helminthosporium oryzae. Indian J. Mycol. Plant Pathol., 4:34-39, 1974.

GOMEZ, K.A. \& GOMEZ, A.A. Statistical procedures for agricultural research. New York, Willey Interscience Publication, 1984. 704p.

JOSHI A, K.; KUMAR, S.; CHAND, R. \& ORTIZ-FERRARA, G. Inheritance of resistance to spot blotch caused by Bipolaris sorokiniana in spring wheat. Plant Breeding, 123:213-219, 2004.

KEULEN, H.van. Plant data. In: KEULEN, H.van. \& WOLF, J., eds. Modelling of agricultural production: Weather, soils and crops. Wageningen, Centre for Agricultural Publications and Documentation, 1986. p.246.

KIM, S.G.; KIM, K.W.; PARK, E. \& CHOI, D. Silicon-induced cell wall fortification of rice leaves: A possible cellular mechanism of enhanced host resistance to blast. Phytopathology, 92:1095-1103, 2002.

KORNDÖRFER, G.H.; ARANTES, V.A.; CORRÊA, G.F. \& SNYDER, G.H. Efeito do silicato de cálcio no teor de silício e na produção de grãos de arroz de sequeiro. R. Bras. Ci. Solo, 23:635-641, 1999.

KORNDÖRFER, G.H.; PEREIRA, H.S. \& NOLA, A. Análise de Si: Solo, planta e fertilizante. Uberlândia, GPSi-ICIAGUFU, 2004. 34p. (Boletim Técnico, 2)

LIANG, Y.C.; MA, T.S.; LI, F.J. \& FENG, Y.J. Silicon availability and response of rice and wheat to silicon in calcareous soils. Comm. Soil Sci. Plant Anal., 25:2285-2297, 1994.

LIANG, Y.C.; SUN, W.C.; SI, J. \& RÖMHELD, V. Effects of foliar and root-applied silicon on the enhancement of induced resistance to powdery mildew in Cucumis sativus. Plant Pathol., 54:678-685, 2005.

MA, J.F.; GOTO, S.; TAMAI, K. \& ICHII, M. Role of root hairs and lateral roots in silicon uptake by rice. Plant Physiol., 127:1773-1780, 2001.

MALAVOLTA, E.; VITTI, G.C. \& OLIVEIRA, S.A. Avaliação do estado nutricional das plantas: Princípios e aplicações. Piracicaba, Potafos, 1997. 319p. 
MENZIES, J.; BOWEN, P.; EHRET, D. \& GLASS, A.D.M. Foliar applications of potassium silicate reduce severity of powdery mildew on cucumber, muskmelon, and zucchini squash. J. Am. Soc. Hortic. Sci., 117:902-905, 1992.

NANDA H.P. \& GANGOPADHYAY, S. Role of silicated cells in rice leaf on brown spot disease incidence by Bipolaris oryzae. Inter. J. Trop. Plant Disease, 2:89-98, 1984.

PEREIRA, H.S.; VITTI, G.C. \& KORNDORFER, G.H. Comportamento de diferentes fontes de silício no solo e na cultura do tomateiro. R. Bras. Ci. Solo, 27:101-108. 2003.

PEREIRA, H.S.; BARBOSA, N.C.; CARNEIRO, M.A.C. \& KORNDORFER, G.H. Avaliação de fontes e de extratores de silício no solo. Pesq. Agropec. Bras., 42:239-247, 2007.

RAFI, M.M. \& EPSTEIN, E. Silicon absorption by wheat (Triticum aestivum L.). Plant Soil, 211:223-230, 1999.

RAIJ, B.van. \& CAMARGO, O.A. Sílica solúvel em solos. Bragantia, 32:223-236, 1973.

RODGERS-GRAY, B.S. \& SHAW, M.W. Substantial reductions in winter wheat diseases caused by addition of straw but not manure to soil. Plant Pathol., 49:590-599, 2000.
SEEBOLD, K.W.; KUCHAREK, T.A.; DATNOFF, L.E.; CORREA-VICTORIA, J.F. \& MARCHETTI, M.A. The influence of silicon on components of resistance to blast in susceptible, partially resistant, and resistant cultivars of rice. Phytopathology, 91:63-69, 2001.

SHANER, G. \& FINNEY, R.E. The effect of nitrogen fertilization on the expression of slow-mildewing resistance in knox wheat. Phytopathology, 70:1183-1186, 1977.

SOUZA, M.A. \& RAMALHO, M.A.P. Genetic control and tolerance to the heat stress in wheat hybrid population and cultivars. Pesq. Agropec. Bras., 36:1245-1253, 2001.

ZANÃO JÚNIOR, L.A. Resistência do arroz à mancha-parda mediada por silício e manganês. Viçosa, MG, Universidade Federal de Viçosa, 2007. 125p. (Tese de Mestrado)

ZANÃO JÚNIOR, L.A.; AVILA, F.R.; FONTES, R.L.F.; NEVES, J.C.L.; KRNDORFER, G.H. Rice resistance to brown spot mediated by silicon and its interaction with manganese. J. Phytopathol., 157:73-78, 2009a.

ZANÃO JÚNIOR, L.A.; FONTES, R.L.F. \& ÁVILA, V.T. Aplicação do silício para aumentar a resistência do arroz à mancha-parda. Pesq. Agropec. Bras., 44:203-206, $2009 \mathrm{~b}$. 